\title{
Archaeological And Historical Importance Of Indian Vedic Site Namisaranaya
}

\author{
Garima Bharti \\ (Research Scholar, Department of Ancient History and Archaeology, Lucknow University U.P., India)
}

\begin{abstract}
Till centuries India has been a place of great religious value and NAMISARAYAN is one of those glorious phase of Indian Vedic history. It describes the huge values of Indian Vedic Purana's, Vedas, Upnishada and Vedic Literature. This site is situated in the state of Uttar Pradesh, District: Sitapur, Tahsil: Mishrikh. As per our Vedic text it is a place of 33 crores Hindu Deities. It is the place where Maharishi Ved Vayasa had written 18 Purana, which are the most important source of India history. This site has famous not only for its historical and religious importance but also for its archaeological importance. The significant art and iconographical evidence of NAMISARAYAN indicates a small but important civilization which had been existed at that time.
\end{abstract}

Keywords: The site of NAMISARAYAN is a famous center of ancient natural medical science. According to puranas, it was a sacrificial land of 84 thousand saints. We can find a great evidence of iconographical deities like Umma - Maheshvra (Parvati - Shiva), Lalita Devi (A form of Parvati), Hanuman, Ram, Sita \& Lakshman in NAMISARAYAN. The site is full of religious places which are of historical importance such that Namisharanaya Chakratirth, Dhadhichi Kund (pond), Manu - Satrupa hermitage, Saunka Rishi Heritage, Vaysa Temple and temple of Lalita devi \& Hanuman Garhi. NAMISARAYAN is also the 11th stop of 84 Koshi (area) revolutions.

\section{INTRODUCTION}

Prestigious consecrate ancient Vedic site NAMISARANAYA (27-26'N-80-35'E) is situated in the state of Uttar Pradesh, District - Sitapur, Tehsil - Mishrikh, India. The site is $35 \mathrm{~km}$ away from Sitapur Headquarter. Namisaranaya is naturally very beautiful and beleaguered by rivers from all four sides i.e. in East Sarayan River, in West Kathana River, in South Sai River and in North by Gomti River which also divided it into two parts. According to Indian Puranas and Vedic literature Namisaranaya is famous from the era of Purana and Tretayuga (period). In this consecrate and holy place, there are lots of historical temple and holy stops in its 84 orbital which are of archaeologically importance as well. But there are very less numbers of research work available on this site and because of this NAMISARAYAN is losing its important history. I want to throw some light on its historical value and archaeological places which are important for case study of this lost site.

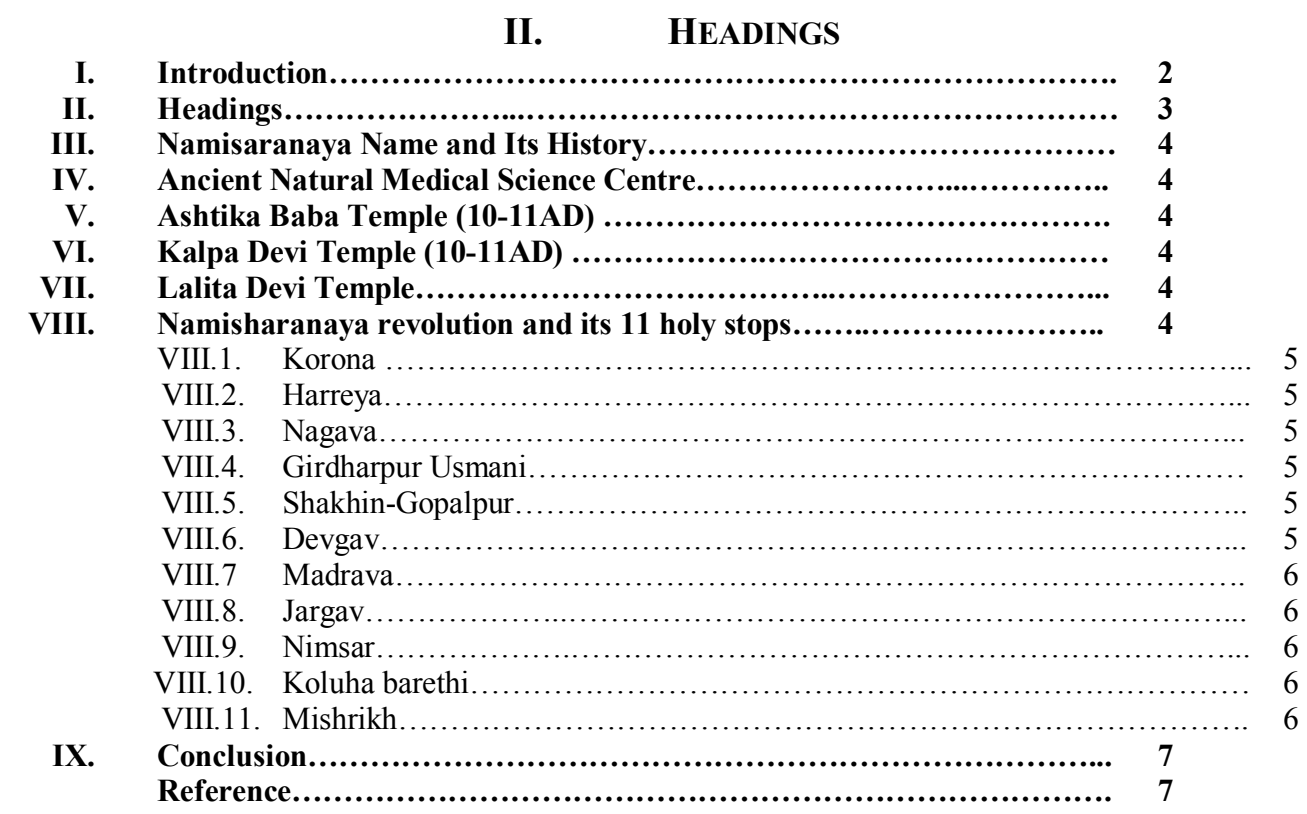




\section{Namisarayan Name and Its History}

The name history of Namisaranaya is very interesting. In earlier days it was called "Nimsar" which means "Place of Azadirachta Indica Tree". In Vedic time there was large amplitude of Azadirachta Indica Tree (Neem) that why it was called Neemsar but later it is modified as Namisaranaya which means "Namis + Aranaya" i.e. (Neem, Azadirachta Indica) + ("The place where there is abundance of Neem trees).

There are so many virtues in Namisaranaya which are significantly important but they have lost their identification due to ignorance. During my research work I came to know some of the very important aspects of this site which are as under:

\section{Ancient Natural Medical Science Centre}

According to Brahma Purana and Vedic literature this place was first ancient natural medical science center. It is also said that Namisarayan is the place where very rare medical vegetation were found in abundance and these vegetation were used by saints to prepare natural medicines for treatment.

\section{Ashtika Baba Temple}

This temple indicates its own significant value. This temple is situated in Namisaranaya. The temple architecture shows $10-11^{\text {th }}$ century Pratihara dynasty phase. This South facing temple is made up by brick and there is a very specific carving on it. Around temple there are five other temples which are totally collapsed and only remains of their platform is there. Currently this temple is being conserved under the supervision of State Archaeology Department Uttar Pradesh.

\section{Kalpa Devi Temple}

Kalpa Devi temple is $5 \mathrm{~km}$ away from Ashtika Baba temple. The main architecture of this temple is Panchayatana type and this temple also belongs to $10^{\text {th }}$ century Pratihara dynasty phase. Kalpa is a form of Parvati, the wife of God Shiva, and that why the statue of this temple resembles Parvati. It is also in under the State Archaeology Department Uttar Pradesh.

\section{Temple Of Lalita Devi}

Lalita Devi temple is situated near by Namisaranayan Chakra Tirha. This temple is one of the Shaktipeeth of Devi Parvati out of a total of 51 in the India. Lalita Devi temple has been a living temple from ancient time to present time while retaining its imporatance. Huge number of Hindu deities icon like UmmaMahesvera, Lalita Devi, Parvati, Hanuman ,Rama Sita Lakshman are there in the temple.

\section{Namisaranaya Revolution and Its 11 Stops}

In ancient Purana's the revolution of Namisaranaya had a very important value. There is a hypothesis that Lord Rama had completed 84 Koshi (area) revolution here itself. This place is also related to Dev Devasura fight incidents and also to Ritual pith of Lalita devi. Great saint Ved Vayasa had written 18 Purana here itself. Another Great Saint Saunka undertook 12 years sacrificial session in Namisarayan and propagated the knowledge of 18 purana to 84 to thousand saints at this holy land.

In current time this revolution area has been divided into two parts by Gomti River. The Northern Part of it is Sitapur District whereas Southern part of it is known as Hardoi district. This revolution starts from "Karona" Place during Falgun Pratipada time (Indian Calendar) and end to "Koluha Barethi" place on the day of Holika Dahan (festival Holi).

\section{VIII.1. Karona}

Karona is the first stop of revolution and is situated $25 \mathrm{~km}$ south from Sitapur on the way of MishrikhSidholi road. There is one hypothesis that in Mahabharata time Kaurav vanshi Pandava's spent here their exile time at this place and that's why initially this place was called as "Kaurav" which got changed to "Karona" at a later stage. In Karona archaeological evidence of red ware were found which include Water Storage Jar, Vessels etc. In the east of Karona place there are two pond which called Ahilya Tirtha and Dvarika Tirtha.

\section{VIII.2. Harreya}

Harreya is second stop of revolution and is situated $60 \mathrm{~km}$ north-east from Hardoi headquarters in Tehsil: Sandila. This place belongs to Shaivism tradition and Anarya was its priest. In medieval time there were two Shiva temples in Harreya which have completely got collapsed and only authentic remains of temple. These remains are of great archaeological importance and also the evidence of temple. 


\section{VIII.3. Nagava}

Nagava is a famous mound which is situated $44 \mathrm{~km}$ away from Hardoi district and $19 \mathrm{~km}$ away from Tehsil Sandila. This place belongs to Naga tradition (Kol-Bhil tribes). Because of Naga Vanshi Shiva votary, this place called as Nagva. In present time people worship snakes here. It is third stop of revolution. In middle of Nagava village, the ruins of a Shiva temple are there. The temple was made up of brick size 32"-26"-5". This temple belongs to Kushana dynasty. The main pilgrim places of Nagava are Garun Ganga, Girija tirth, Hatyaharan and Narmeshvara.

\section{VIII.4. Girdharpur Usmani}

It is the fourth stop situated $55 \mathrm{~km}$ away from Hardoi district and $16 \mathrm{~km}$ from Nagava mound. In the east of the Girdharpur village a huge lake is there which is called Nivarsa Lake. Adjacent to this Lake a mound is there which retains the ruins of old temple and is the main place of fourth stop of the revolution.

\section{VIII.5. Sakhin}

This place is situated $45 \mathrm{~km}$ north from Hardoi headquarters and $45 \mathrm{~km}$ west from Tehsil Sandila. Sakhin is the fifth stop. It is also an important archaeological site as ruins of an ancient Shiva temple and medieval period structures are still there. These ruins resembles of red ware Handi, Jars, Vessel, Big Jar (Nad).

\section{VIII.6. Devgav}

Devgav is situated $22 \mathrm{~km}$ south from Sitapur headquarters and $15 \mathrm{~km}$ west from Tehsil Mishrikh on the way of Ramkot, Kutub Nagar. In the west of this place there is a pond which in earlier days was called Dev Prayaga but now it is known Devgav. A lot of ruins which indicates Kushana time period structure were found around the mound fortification wall. Remains of potteries, bricks and the collapsed icon of Mahishmardini Durga, Nari Devi and Vishnu have been founded into collapsed Shiva temple.

\section{VIII.7. Madrava}

This Madrava mound is situated $18 \mathrm{~km}$ south from Sitapur headquarters and $8 \mathrm{~km}$ north east from Mishrikh Tehsil. Kusana and medieval time structure, a big Shiva temple were established on mound in earlier time. The brick of temple's lower part indicates Kushana period. This place is also belongs to Nagavanshi (Specially Kol, Bhil, Sanyal tribes).

\section{VIII.8. Jargav}

Jargav mound of is situated $50 \mathrm{~km}$ north from Hardoi and after Madrava stop on the way of Sandila Vani marg. This is a huge mound which has $10-11^{\text {th }}$ century archaeological remains scattered all over the mound. The mound is also the evidences of Maurya and Kushana time brick wall.

\section{VIII.9. Namisaranaya Chakratirth}

Namisaranaya is most significant stop of all stops. According to Padma Purana chakra, Vishnu prostrates here that why this place is called Chakra tirth. Namisarayan is also having a huge pond. According to Balmiki Ramayana big Ashva Medh Yagya held in Namisaranaya and Loard rama had also done a sacrificial here. According to Bhagavat Purana Namisharanya is a Vaishnava place. According to Brahama Purana, it sacrificial place of saints and the place of Devi Umma . It is also Shaktipith of Lalitadevi.

\section{VIII.10. Koluha Barethi}

This is the tenth stop of revolution. This mound is situated $37 \mathrm{~km}$ south from Sitapur headquarters and $12 \mathrm{~km}$ away from Tehsil Mishrikh. In ancient time there was huge population of tribes Kol, Bhils. These populations were related to Nagavanshi culture. This place was named after those tribes as Kol to Koluha and Bhil to Barethi that's why Koluha Barethi.

\section{VIII.11. Mishrikh}

It is the last stop of revolution. Misrikh site is situated $24 \mathrm{~km}$ south from Sitapur on the way to SitapurHardoi road. Mishrikh have its own importance. It is famous for Dhadhichi Kunda (Pond) and also for its vegetation. According to Auranas this place belongs to Hindu deity Indra and Asura Vrattasur battle, in which saint Dhadhichi contributed his bone to deva Indra for victory.

\section{Conclusion}

In Nutshell, Namisaranaya site is historically as well as archaeologically very rich from evidence points of view. It defines and describes the culture of past Indian Vedic era. But again this site lacks the numbers of research works and specific archaeological excavation. The site is specially relates to Vedic (10-7 BC), 
Mahabharta (6-5 BC) time but we found choronological secquence of Mauryan period (3-2BC), Kushana period (1-2AD), Pratihara times (10-11AD) and medieval period. This site is a center of all Hindu religions like Shaivism, Vaishnavism, Shaktism.yet we found the archaeological remains of specific period but in present all sites are in veil and lost its glory.this ancient site Namisaranaya needs a lot of archaeological work, excavation, historical argument which unveil the lost history of this place.

[1] Dhyanam Journal Vol.2 Year (1982)

\section{REFERENCES}

[2] District Gazette, Sitapur

[3] Amritlal Nagar, Ekada Namisharanaya (1988)

[4] Rakesh Kumar Srivastava, Protected Monument Of Uttar Pradesh, Uttar Pradesh State Archaeology (2002) 